\title{
Keratitis by Aspergillus flavus infection after cataract surgery
}

\author{
Ceratite por infecção com Aspergillus flavus \\ após facoemulsificação
}

João Luiz Pacini Costa', Daniel Barra', Edson Ando¹ Robert Pogue ${ }^{2}$

\begin{abstract}
We report a case of keratis infection after cataract phacoemulsification with intraocular lens implantation in a 65-year-old female patient. The patient initially underwent cataract surgery on the right eye. Intraocular inflammation appeared on the second post-operative day and was initially treated as Toxic Anterior Segment Syndrome (TASS). The inflammation was reduced and vision improved initially but very aggressive and progressive keratitis destroyed the cornea due to the delay in correct diagnosis. Aspergillus flavus was isolated from a biopsy. The infection was treated with antifungal agents and loss of the eye was avoided by total corneal transplantation associated with Gundersen conjunctiva cover. To restore the lost vision, a second penetrating corneal graft with removal of the conjunctiva cover was performed 17 months later. The final best-corrected vision was 20/40 but prognosis for long-term graft survival is poor.
\end{abstract}

Keywords: Aspergillus; Endophthalmitis; Keratitis; Phacoemulsification; Cataract; Case reports

\section{RESUMO}

Nós relatamos um caso de ceratite após facoemulsificação de catarata com implantação de lente intraocular em uma paciente de 65 anos. A paciente inicialmente passou cirurgia para catarata no olho direito. A inflamação apareceu no segundo dia pós-cirurgia, inicialmente tratada como Toxic Anterior Segment Syndrome (TASS). A inflamação foi reduzida e a visão melhorou, porém uma ceratite progressiva e agressivo destruiu a córnea devido à demora do diagnóstico correto. O fungo Aspergillus flavus foi isolado de uma biópsia. A infecção foi tratada com agentes antifúngicos e a perda do olho foi evitada por transplantação da córnea associada com cobertura da conjuntiva tipo Gunderson. Para recuperar a visão, um segundo enxerto corneal penetrante com remoção da cobertura conjuntival foi realizado após 17 meses. A qualidade visual final era 20/40, porém o prognóstico para sobrevivência do enxerto no longo prazo é negativo.

Descritores: Aspergillus; Endoftalmite, Keratite, Facoemulsificação; Catarata; Relatos de casos

\footnotetext{
1 Visão Institutos Oftalmológicos Associados - Brasília (DF), Brazil;

${ }^{2}$ Laboratório de Ciências Genômicas e Biotecnologia, Universidade Católica de Brasília - Brasília (DF), Brazil.

Study carried out at Visão Institutos Oftalmológicos Associados and Universidade Católica de Brasília, Brasília (DF), Brazil. The authors deeclare no conflicts of interests.

Received for publication 23/09/2015 - Accepted for publication 10/11/2015
} 


\section{INTRODUCTION}

$\mathbf{E}$ ndophthalmitis following cataract surgery is a relatively rare complication, however, the severity of the consequences, together with data suggesting that the incidence is increasing ${ }^{(1)}$, demand vigilance regarding this phenomenon. The most frequent cause of endophthalmitis is grampositive bacteria, with fungal infection being a rarer etiology ${ }^{(1)}$.

Mycotic infections of the eye are an important cause of blindness ${ }^{(2)}$. They most commonly occur as a result of trauma, but have been reported following ocular surgery, resulting in pathologies including scleritis and keratitis ${ }^{(3)}$. Aspergillus flavus is a less frequent cause of infections than A. fumigatus, but is more virulent, and is more frequently found in air in some geographical regions ${ }^{(4-7)}$. Furthermore, it occurs more frequently in superficial infections.

We report a case of inflammation after phacoemulsification with intraocular lens implantation initially treated as Toxic Anterior Segment Syndrome (TASS) but later progressing as a very aggressive keratis that destroyed the entire cornea.

\section{Case Report}

A 65-year-old female, a smoker, with a history of left pulmonary superior lung resection underwent an uneventful phacoemulsification surgery of nuclear +2 senile cataract with left intra-ocular lens implantation. We used topical anesthesia and the surgery was performed with a temporal clear corneal incision of $2.75 \mathrm{~mm} 3$-plane tunnel, $5 \mathrm{~mm}$ curvilinear capsulorhexis, phacoemulsification and complete in-the-bag 3-piece intra-ocular lens implantation (Sensar- Ar 40 AMO). The ophthalmic viscosurgical device (OVD) was removed and the incision and side port were hydrated by injection of balanced salt solution (BSS, Alcon Laboratories) in order to seal the incision. The postoperative period was unremarkable with visual acuity of 20/20. Topical eye drops of Moxifloxacin Hydrochloride Ophtalmic solution $0.5 \%$ (Alcon) and Dexamethasone Phosphate $0.1 \%$ (Alcon) 4X/day were applied during a four-week period with a decrease of one daily dose per week. The right eye was scheduled for the same surgery and a Sensar- Ar 40 (Amo) intra-ocular lens implantation with BSS injection for sealing of the incision and the side port.

\section{Fungal identification was carried out by microbial culture.}

On the second post-operative day of the right eye, intraocular inflammation was noted and the patient was treated for TASS with increased eye drops plus topical tropicamide. There was a complete recovery of the intra-ocular signs of inflammation, disappearance of pain, and visual acuity returned to 20/40. Initial superficial keratitis (Figure 1) was noted and registered with digital imagery by slit lamp in the limbal area of 1-2 mm. Mild inflammation recurred and a vitreous biopsy was done with injection of vancomycin and cetazidime inside the vitreous cavity.

The steroid eye-drops were decreased but despite the unreactive anterior chamber the keratitis worsened, turning into an aggressive and progressive infection of the right cornea. The correct diagnosis was made after a second biopsy showing presence of a filamentous fungus, confirmed as Aspergillus flavus. Application of amphotericin B and complete suspension of steroids and oral intake of kenatozole did not prevent melting of almost the entire cornea (Figure 2).
The infection was controlled by antifungal agents and loss of the eye was avoided by total corneal transplantation associated with Gundersen conjunctiva cover ${ }^{(8)}$ (Figure 3).

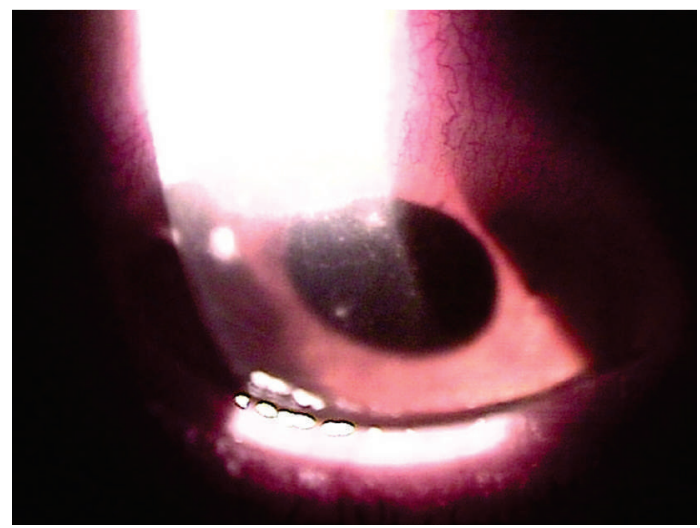

Figure 1: Improvement with topical steroids; initial keratitis possibly from canula seeding

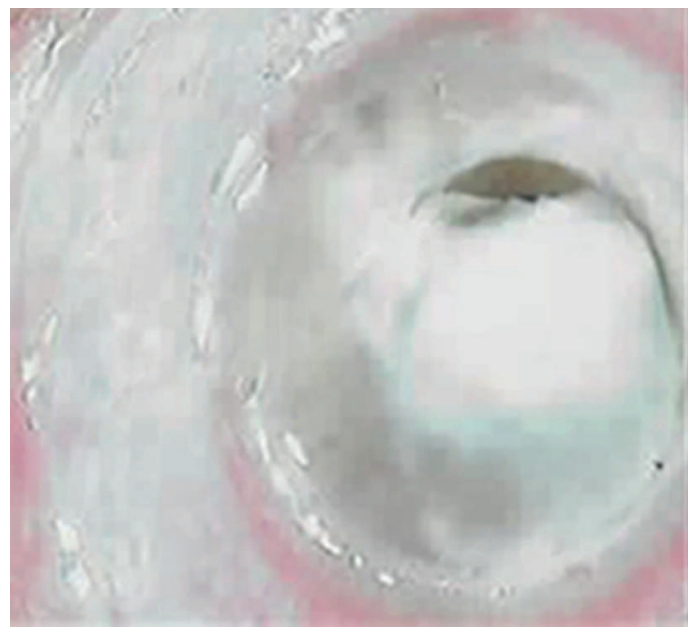

Figure 2: Total corneal melting with spontaneous eye perforation

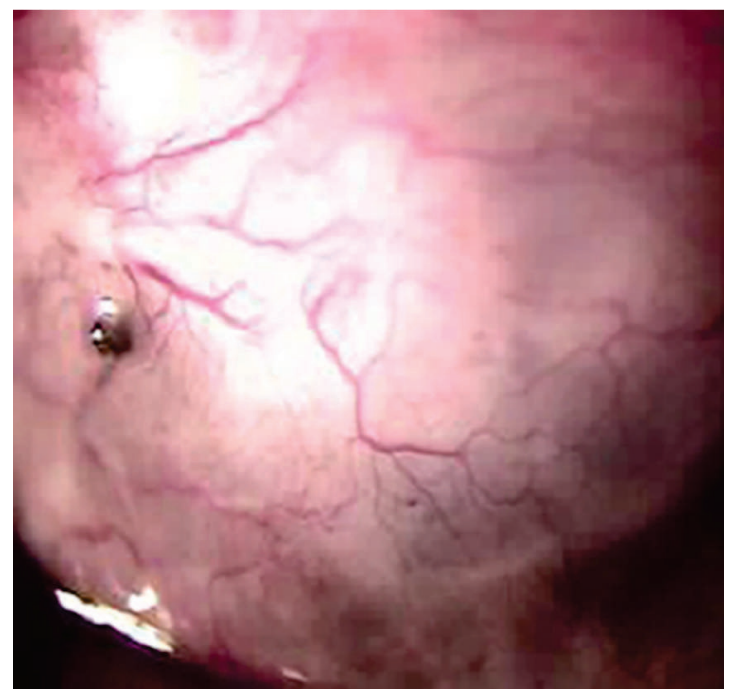

Figure 3: Eye 6 months after total corneal transplantation with Gunderson conjunctival cover 
After this surgery the patient was treated with intravenous voriconazole for seven days. The infection was finally controlled and final visual acuity was hand movements. EcoGraphic images showed no alterations of the intra-ocular structures with attached retina. No changes were noted and the anterior segment became cloudy.

Seventeen months after the keratitis diagnosis we performed a second $9 \mathrm{~mm}$ penetrating keratoplasty with conjunctival removal. The affected eye was $20 / 40$ with bestcorrected vision. The final corneal biopsy was free of the fungus. The patient is being followed closely, due to a high risk of cornea opacification through possible corneal rejection ${ }^{(9,10)}$.

\section{Discussion}

Particularly relevant is the fact that $A$. flavus shows greater prevalence in hot, dry countries, and in hospital air ${ }^{(6)}$. The patient's problems occurred during the Brazilian dry season. Delayed diagnosis was probably the reason for loss of the cornea and the final visual deficiency. TASS was first suspected and the continuous and vigorous use of topical steroids in a patient with a history of pulmonary problems and tabagism may have worsened the clinical outcome and the aggressiveness of the $\operatorname{keratitis}^{(7)}$. The vitreous biopsy showed no intraocular microorganisms, leading to a diagnosis of primary infection of the cornea. The pattern of the corneal lesions observed in the first images taken led us to the hypothesis of seeding of Aspergillus by the canula used to hydrate the incision and the paracenthesis. Intrastromal injections of voriconazole could have been used in this with less adverse effects ${ }^{(7)}$. This local treatment could have been applied to produce better results. Despite this being an extremely rare case, we report it in order to alert colleagues about the first signs of fungus keratitis, especially considering that such a situation may mimic other types of inflammation ${ }^{(1)}$. Precaution must be taken in the use of steroid eye-drops ${ }^{(2)}$ because they might hide the correct diagnosis of fungus keratitis in its early phase. The pattern observed in Figure 1 shows the early signs of the seeding of the fungus inside the corneal stoma.

Fungal infection of the self-sealing tunnel incision can pose a diagnostic and therapeutic challenge ${ }^{(9)}$, frequently resulting in the need for additional surgery ${ }^{(2,6)}$. To facilitate early diagnosis and rapid identification of the infectious agent, this should be considered in the differential diagnosis of cases presenting as sclerotic or with excessive postoperative reaction after cataract surgery in geographic areas with a hot and humid climate ${ }^{(4,6,7)}$.

\section{Conclusion}

The source of the Aspergillus flavus may have been the patient's own secretions which may have contaminated the canula used to seal the incision and the side port, directly bringing the infection inside the cornea. The canula could also have been contaminated by a defect in the surgery drape and/or contact with the patient's own respiratory secretions in the periocular skin. The long-term prognosis for graft survival is not positive due to the high risk of rejection.

\section{ReFERENCES}

1. West ES, Behrens A, McDonnell PJ, Tielsch JM, Schein OD. The incidence of endophthalmitis after cataract surgery among the U.S. Medicare population increased between 1994 and 2001. Ophthalmology. 2005;112(8):1388-94.

2. Thomas PA. Current perspectives on ophthalmic mycoses. Clin Microbiol Rev. 2003;16(4):730-97.

3. Bernauer W, Allan BD, Dart JK. Successful management of Aspergillus scleritis by medical and surgical treatment. Eye (Lond). 1998;12(2):311-6.

4. Hedayati MT, Pasqualotto AC, Warn PA, Bowyer P, Denning, DW. Aspergillus flavus: human pathogen, allergen and mycotoxin producer. Microbiology. 2007;153(6):1677-92.

5. Adhikari A, Sen MM, Gupta-Bhattacharya S, Chanda S. Airborne viable, non-viable, and allergenic fungi in a rural agricultural area of India: a 2-year study at five outdoor sampling stations. Sci Total Environ. 2004;326(1-3):123-41.

6. Jafarinasab MR, Feizi S, Yazdizadeh F, Rezaei Kanavi M, Moein HR. Aspergillus flavus_keratitis_after_deep_anterior_lamellar keratoplasty. J Ophthalmic Vis Res. 2012;7(2):167-71.

7. Jafarinasab MR, Feizi S, Yazdizadeh F, Rezaei Kanavi M, Moein HR. Aspergillus flavus keratitis after deep anterior lamellar keratoplasty. J Ophthalmic Vis Res. 2012;7(2):167-71.

8. Punia RS, Kundu R, Chander J, Arya SK, Handa U, Mohan H. Spectrum of fungal keratitis: clinicopathologic study of 44 cases. Int J Ophthalmol. 2014;7(1):114-7.

9. Gundersen T, Pearlson HR. Conjunctival flaps for corneal disease: their usefulness and complications. Trans Am Ophthalmol Soc. 1969;67:78-95.

10. Thompson RW Jr, Price MO, Bowers PJ, Price FW Jr. Long-term graft survival after penetrating keratoplasty. Opthalmology. 2003;110(7):1396-402.

\section{Corresponding author:}

Robert Pogue

SGAN 916, Modulo B - Asa Norte,

Zip Code: 70790-160 - Brasília (DF), Brazil

Fax: +55-61-3347-4797

E-mail: redward@ucb.br 